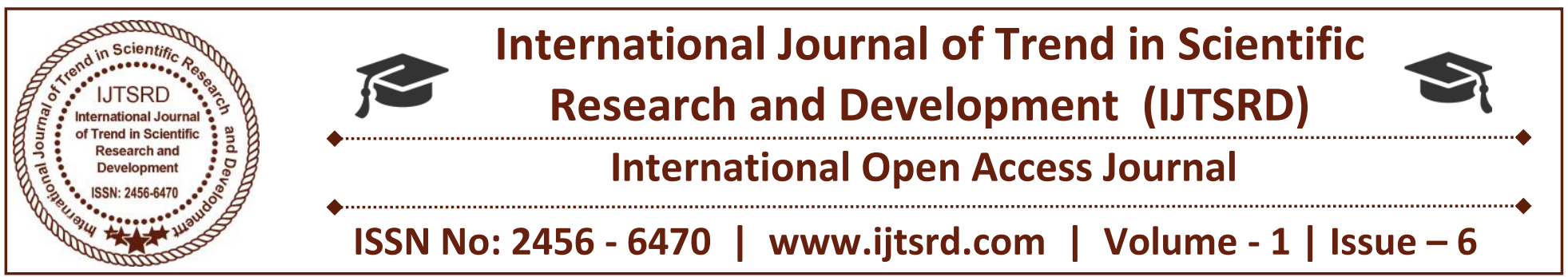

\title{
Study on Views of Customers on Retail Banking Products of Banking Industry in Krishna District, A.P.
}

\section{Dr. Talluri Sreekrishna}

Research Supervisor, Dept. of Management Sciences,

R.V.R \& J.C. College of Engineering,

Chowdavaram, Guntur, Andhra Pradesh, India

\author{
Karlapudi Ramesh Babu \\ Research Scholar, Dept. of Commerce and Business \\ Administration, Acharya Nagarjuna University, \\ Nagarjuna Nagar,Guntur, Andhra Pradesh, India
}

\begin{abstract}
Savings and investments are the most important ingredients of capital formation for an economy; therefore, the promotion of domestic savings is a must to boost the process of capital formation and development. The commercial banks are in the nature of a catalyst, converting savings into capital for productive investment. It is needless to say that capital formation largely depends on the effectiveness of these institutions. Thus, the commercial banks play stupendous role in converting potential investments into real and can make a significant contribution in eradicating poverty, unemployment and in bringing about progressive reduction in inter-regional and inter-sector disparities through rapid expansion of banking services.
\end{abstract}

The commercial banks help in developing both internal and external trade of a country. Banks provide loans to retailers, traders, wholesalers for their inventory and also help in transporting of goods from one place to another by providing all types of facilities, such as discounting and accepting bills of exchange, providing overdraft facilities, issuing drafts, etc. The industrial sector is also not away from the help of the commercial banks. Banks finance the industrial sector in many ways. They provide short term, medium term and long-term loans to the industry. Export promotion requires adequate preshipment packing credit, which is also, made available by these banks in the form of loans, cash credit and overdraft facilities.

Banks by providing loans to the investors and consumers, are not only helping in increasing the standards of living of the people, but also help in reducing the recession in the economy through enhancing the demand for raw material and finished goods that ultimately leads to increase in the employment opportunities. Apart from the basic banking services such as deposits, loans and advances, banks have been traditionally rendering certain ancillary services also to their customers, such as: remittances, demand drafts, mail transfers, and telegraphic transfers, sale and purchase of exchange, locker facilities, safe custody and safe deposit vaults, guarantee facilities, sale of traveller's cheques, trustier and executor services etc. Among the services introduced by modern commercial banks during the last quarter of the century, the bank designed a system by which a bank's customer with many payments to make, instead of drawing a cheque for each item, may simply instruct the bank to transfer to the accounts of his creditors the sum due from him and he writes one cheque debiting his account with the total amount; By providing these diversified services, banks help in the growth of trade and industry to great extent. 
Modern commercial banks in order to diversify their activities, entered into new non-traditional areas of business, such as mutual funds, merchant-banking activities, portfolio management, corporate counselling, and hire purchase finance, equipment leasing, venture capital and factoring service. These new activities result in the development of industry and trade in the country. In brief, it can be said that banks constitute the very lifeblood of economic society.

\section{Need for the Study}

The Banking industry has undergone rapid changes in the recent past after reforms in the financial sector especially after reforms with banking sector. The nature, size and structure of banking sector underwent severe threats and challenges. Retail banking is one of the areas which have drawn attention of the policy makers, executives and customers. It is in this context, the present study assumes significance.

\section{Nature of the Study}

The present study makes a comparative analysis of the select banks on products relating to Retail Banking.

\section{Scope of the Study}

Scope of the study is to understand the various services and the products offered by the banks to the individual customers and to find out the gaps in the services being offered and the customer expectations. An effort is also made to suggest the banks as to where the gaps exist and what needs to be done to close the gaps. The study also covered the problems faced by the executives in providing retail banking products to customers. The study is confined to KrishnaDist., as the investigator has more access to the officials of the banks as well as customers of the banks. The present study includes the retail products and services which are offered by select banks like Savings Bank a/c, FDRs, loans, technical services, mutual funds and insurances etc. The problems of both customers and executives are also analysed in utilising and providing these services.

\section{OBJECTIVES OF THE STUDY}

The following are the objectives of the study.

1. To discuss the growth and development of banking in India before and after reforms.

2. To present the frame work relating to retail banking, it constituents, problems, prospects etc.

3. To study the profiles of select banks and also to understand their retail banking practices.
4. To elicit the views of customers on the retail banking products of the banks under study.

5. To offer suggestions to the decision making authorities after drawing conclusion from the study.

\section{Methodology of the Study}

\section{Sample}

The investigator wrote to almost all the public and private sector banks to their head quarters to give permission to study their Retail Banking practices. However, with lot of efforts he could obtain permission from three banks to collect information in Krishna,district, they are

1. State Bank of India(a leading largest bank operating at National level).

2. ICICI Bank(a leading bank in private sector)

3. Andhra Bank (A leading bank operating at regional level).

The investigator planned to collect data from 400 customers. But due to resistance from customers and also due to various other constraints the investigator could collect responses from 278 customers of select banks in Krishnadistrict. It is to be noted that convenience sampling technique has been employed in the study.

\section{Sources of Data}

a. Primary data.

b. Secondary data

\section{Primary Data}

Primary data are those that are original in character and are collected afresh as the primary data is information collected for the first time. Primary data can be mainly collected by a well designed questionnaire. There are several methods in which the data is collected.

\section{SECONDARY DATA}

Secondary data refers to the use of information already collected and published or unpublished.

\section{Sources of Secondary data}

$>$ Annual reports of the banks.

> Textual information available in the library.

$>$ Web sites.

$>$ Magazines. 


\section{Data Analysis}

This is the process which helps to eliminate the unnecessary data and to collect relevant information which helps in problem solving and to overcome the problem of an enterprise or an organization. The collected data was analyzed with the help of statistical tools like percentages, Weighted Average, Standard Deviation, Co-efficient of Variance, one way ANOVA etc.

Table 1: Retail Banking Products considered by respondent customers

\begin{tabular}{|c|c|c|c|c|c|c|c|c|}
\hline \multirow{2}{*}{$\begin{array}{l}\text { Retail } \\
\text { Products }\end{array}$} & \multirow{2}{*}{$\begin{array}{l}\text { No. of } \\
\text { Respondents }\end{array}$} & \multirow{2}{*}{$\begin{array}{l}\text { Percentage } \\
(\%)\end{array}$} & \multicolumn{2}{|c|}{ SBI } & \multicolumn{2}{|l|}{$\mathrm{AB}$} & \multicolumn{2}{|c|}{ ICICI } \\
\hline & & & $\mathbf{N}$ & $\%$ & $\mathbf{N}$ & $\%$ & $\mathbf{N}$ & $\%$ \\
\hline SB \& FDR & 118 & 31.55 & 56 & 34.15 & 44 & 41.12 & 18 & 17.48 \\
\hline Personnel Loans & 94 & 25.13 & 38 & 23.17 & 26 & 24.30 & 30 & 29.13 \\
\hline Technical Services & 78 & 20.86 & 35 & 21.34 & 19 & 17.76 & 24 & 23.30 \\
\hline MF \& Insurance & 56 & 14.97 & 24 & 14.63 & 10 & 9.35 & 22 & 21.36 \\
\hline All the above & 28 & 7.49 & 11 & 6.71 & 8 & 7.48 & 9 & 8.74 \\
\hline TOTAL & 374 & 100.00 & 164 & 100 & 107 & 100 & 103 & 100 \\
\hline
\end{tabular}

The analysis relating to views of respondents on Retail Banking Products is furnished in table 1. The respondents are asked to give their views on Retail banking products which are offered by the banks under study. SB accounts \& FDR are considered as major retail banking products by a large no of respondents. The respondents of both SBI and AB also favored the same products. However, the respondents of ICICI have given priority for Personal Loans followed by technical services, mutual funds and insurance etc. The respondents of SBI and AB have given second priority to personal loans and others.

\section{Table 2: Retail Banking Products used}

\begin{tabular}{|c|c|c|c|c|c|c|c|c|}
\hline \multirow{2}{*}{$\begin{array}{l}\text { Usage of Retail } \\
\text { Banking Products }\end{array}$} & \multirow{2}{*}{$\begin{array}{l}\text { No. of } \\
\text { Respondents }\end{array}$} & \multirow{2}{*}{$\begin{array}{l}\text { Percentage } \\
(\%)\end{array}$} & \multicolumn{2}{|l|}{ SBI } & \multicolumn{2}{|l|}{$\mathbf{A B}$} & \multicolumn{2}{|c|}{ ICICI } \\
\hline & & & $\mathbf{N}$ & $\%$ & $\mathbf{N}$ & $\%$ & $\mathbf{N}$ & $\%$ \\
\hline SB \& FDR & 180 & 48.13 & 96 & 51.06 & 54 & 42.86 & 30 & 50.00 \\
\hline Personnel Loans & 58 & 15.51 & 28 & 14.89 & 24 & 19.05 & 6 & 10.00 \\
\hline Technical Services & 75 & 20.05 & 33 & 17.55 & 30 & 23.81 & 12 & 20.00 \\
\hline MF \& Insurance & 46 & 12.30 & 24 & 12.77 & 12 & 9.52 & 10 & 16.67 \\
\hline All of the above & 15 & 4.01 & 7 & 3.72 & 6 & 4.76 & 2 & 3.33 \\
\hline TOTAL & 374 & 100.00 & 188 & 100.00 & 126 & 100.00 & 60 & 100.00 \\
\hline
\end{tabular}

The usage of Retail banking products by the all the three select banks. While relatively low of respondent customers is presented in table 2. The them use all the Retail Banking products of the select table shows that SB and FDR products have been banks. used by about 50 per cent of respondent customers of

Table 3: Time taken to open Savings Bank A/C

\begin{tabular}{|c|c|c|c|c|c|c|c|c|}
\hline \multirow[t]{2}{*}{ Time Taken } & \multirow{2}{*}{$\begin{array}{l}\text { No. of } \\
\text { Respondents }\end{array}$} & \multirow{2}{*}{$\begin{array}{l}\text { Percentage } \\
(\%)\end{array}$} & \multicolumn{2}{|l|}{ SBI } & \multicolumn{2}{|c|}{$\mathbf{A B}$} & \multicolumn{2}{|c|}{ ICICI } \\
\hline & & & $\mathbf{N}$ & $\%$ & $\mathbf{N}$ & $\%$ & $\mathbf{N}$ & $\%$ \\
\hline$<25$ minutes & 31 & 11.15 & 7 & 6.14 & 7 & 7.14 & 17 & 25.76 \\
\hline $25-35$ minutes & 36 & 12.95 & 15 & 13.16 & 12 & 12.24 & 9 & 13.64 \\
\hline $35-45$ minutes & 98 & 35.25 & 24 & 21.05 & 45 & 45.92 & 29 & 43.94 \\
\hline$>45$ minutes & 113 & 40.65 & 68 & 59.65 & 34 & 34.69 & 11 & 16.67 \\
\hline TOTAL & 278 & 100.00 & 114 & 100 & 98 & 100 & 66 & 100 \\
\hline
\end{tabular}


The time taken to open Savings Banks account is furnished in table 3.According to this it took more than 45 minutes for majority of respondent customers. It took the same time for about 60 per cent of respondent customers of SBI while for majority of respondent customers of other banks i.e. $\mathrm{AB}$ and
ICICI, they could complete the transaction in below 45 minutes. This implies that there are significant differences in the time taken to open SB a/c in case of the three select banks.

Table 4: Time taken to deposit money

\begin{tabular}{|c|c|c|c|c|c|c|c|c|}
\hline \multirow{2}{*}{ Time Taken } & \multirow{2}{*}{$\begin{array}{l}\text { No. of } \\
\text { Respondents }\end{array}$} & \multirow{2}{*}{$\begin{array}{l}\text { Percentage } \\
(\%)\end{array}$} & \multicolumn{2}{|l|}{ SBI } & \multicolumn{2}{|c|}{$\mathrm{AB}$} & \multicolumn{2}{|c|}{ ICICI } \\
\hline & & & $\mathbf{N}$ & $\%$ & $\mathbf{N}$ & $\%$ & $\mathbf{N}$ & $\%$ \\
\hline Less than 25 minutes & 32 & 11.51 & 10 & 8.77 & 7 & 7.14 & 15 & 22.73 \\
\hline 25-35 minutes & 49 & 17.63 & 22 & 19.30 & 6 & 6.12 & 21 & 31.82 \\
\hline 35-45 minutes & 102 & 36.69 & 58 & 50.88 & 24 & 24.49 & 20 & 30.30 \\
\hline More than 45 minutes & 95 & 34.17 & 24 & 21.05 & 61 & 62.24 & 10 & 15.15 \\
\hline TOTAL & 278 & 100.00 & 114 & 100 & 98 & 100 & 66 & 100 \\
\hline
\end{tabular}

The details relating to time taken to deposit money is shown in table 4.7(2). In case of majority of respondent customers of total as well as SBI, it took 35-45 minutes to deposit their money, the respondent customers of $\mathrm{AB}$ and ICICI differed significantly in this regard. It can be concluded that there are significant differences in the views of respondent customers on the time taken to deposit money

Table 5: Time taken for withdrawal of money from ATMs

\begin{tabular}{|c|c|c|c|c|c|c|c|c|}
\hline \multirow{2}{*}{ Time Taken } & \multirow{2}{*}{$\begin{array}{l}\text { No. of } \\
\text { Respondents }\end{array}$} & \multirow{2}{*}{$\begin{array}{l}\text { Percentage } \\
(\%)\end{array}$} & \multicolumn{2}{|l|}{ SBI } & \multicolumn{2}{|c|}{ AB } & \multicolumn{2}{|c|}{ ICICI } \\
\hline & & & $\mathbf{N}$ & $\%$ & $\mathbf{N}$ & $\%$ & $\mathbf{N}$ & $\%$ \\
\hline Less than 25 minutes & 124 & 44.60 & 48 & 42.11 & 59 & 60.20 & 17 & 25.76 \\
\hline 25-35 minutes & 95 & 34.17 & 37 & 32.46 & 18 & 18.37 & 40 & 60.61 \\
\hline $35-45$ minutes & 46 & 16.55 & 23 & 20.18 & 15 & 15.31 & 8 & 12.12 \\
\hline More than 45 & 13 & 4.68 & 6 & 5.26 & 6 & 6.12 & 1 & 1.52 \\
\hline TOTAL & 278 & 100.00 & 114 & 100 & 98 & 100 & 66 & 100 \\
\hline
\end{tabular}

The time taken to withdrawal money from ATMs also plays a significant role in Retail Banking products of the banks. In case of good no. of respondent customers of total as well as SBI and AB, it took less than 25 minutes for withdrawal from ATMs. In case of respondent customers of ICICI, it took more than 25 minutes. These details are available from table 5 . It can be inferred that there are significant differences in the time taken to withdraw money from ATM's.

Table 6: Time taken to issue cheque books.

\begin{tabular}{|c|c|c|c|c|c|c|c|c|}
\hline \multirow[t]{2}{*}{ Time Taken } & \multirow{2}{*}{$\begin{array}{l}\text { No. of } \\
\text { Respondents }\end{array}$} & \multirow{2}{*}{$\begin{array}{l}\text { Percentage } \\
(\%)\end{array}$} & \multicolumn{2}{|l|}{ SBI } & \multicolumn{2}{|c|}{$A B$} & \multicolumn{2}{|c|}{ ICICI } \\
\hline & & & $\mathbf{N}$ & $\%$ & $\mathbf{N}$ & $\%$ & $\mathbf{N}$ & $\%$ \\
\hline Less than 2 days & 12 & 4.32 & 6 & 5.26 & 4 & 4.08 & 2 & 3.03 \\
\hline 2-4 days & 89 & 32.01 & 45 & 39.47 & 26 & 26.53 & 18 & 27.27 \\
\hline 4-6 days & 142 & 51.08 & 51 & 44.74 & 61 & 62.24 & 30 & 45.45 \\
\hline More than 6 days & 35 & 12.59 & 12 & 10.53 & 7 & 7.14 & 16 & 24.24 \\
\hline TOTAL & 278 & 100.00 & 114 & 100 & 98 & 100 & 66 & 100 \\
\hline
\end{tabular}

The time taken to issue cheque books is almost similar to majority of total respondents' customers as well as respondents of the respective banks viz. SBI, $\mathrm{AB}$ and ICICI. The information from 4.7(4) 
confirmed this analysis. This shows that there are no significant differences relating to the time taken to issue cheque books.

\section{FINDINGS}

$>$ There were significant differences among the views of respondents of bank on the perception relating to the retail banking products as offered by the respective banks. The respondents of SBI and $\mathrm{AB}$ are of the view that SB \& FDR constitute retail banking products while the respondents of ICICI considered personal loans, technical services, mutual funds and insurance also as part of the retail banking products. SB and FDR's have been used by the majority of the respondents of select banks. Other products are used by few respondents only. The statistical analysis shows that there are significant differences which are observed in case of retail banking products.

$>$ There are significant differences which are found in case of views of respondents relating to transaction of savings banks.

i) $\mathrm{SBI}$ took more time when compared to $\mathrm{AB}$ and ICICI to open savings bank $\mathrm{a} / \mathrm{c}$.

ii) The time taken to deposit money varies significantly with respect to select banks.

iii) In case of the time taken to withdraw money from ATM's, differences are observed in the views of respondents of SBI, AB and ICICI.

iv) There were no significant differences in the views of respondents on the time taken to issue cheque books.

v) On the whole, the services relating to $\mathrm{SB}$ a/c was perceived as excellent by majority of respondents of all banks which are under study.

FDR(Fixed Deposit Receipt) is another retail banking product which attracts customers. The majority of customers of select banks are satisfied with the time taken to receive FDR, time taken for renewal/withdrawal etc. Very few customers have faced some delay in completing of transactions.

\section{SUGGESTIONS}

$>$ As it was observed in the analysis that the procedure to obtain loan was opined as lengthy which requires a number of documents to be filled by the customers, it may be suggested that the procedure needs to be simplified which will also help to reduce the paper work. This will help to reduce the strain and stress of the customers also.

$>$ Before introducing the retail products, proper planning is to be done with reference to the requirements and expectations of customers. This will help to improve co-ordination with the advancements in technology; the customers are expecting more and more new retail products to make their savings and investment pattern more comfortable. It is in this context a proper coordinations is required to be achieved at the different levels of bank managements.

Innovation, creativity and attracting are the key words which are applicable to any industry. The banking sector is no more an exception to this phenomena. The banks need to reinvent the retail products as to attract the customers to improve the business of the banks. For example SBI recently introduced two new varieties of services through ATM's; they are deposit of money and transfer of money from one account to other. So, these types of facilities may be extended by other banks also to improve the profitability and to satisfy customers.

$>$ The bankers should use the various media available in educating the public on different retail banking products which are being implemented by banks. Sincere and honest customers must be honoured on the public platforms to motivate the remaining customers.

\section{CONCLUSION}

Retail banking is the fastest growing sector of the banking industry with the key success by attending directly to the needs of the end customers which will have glorious future in coming years. Retail banking sector as a whole is facing a lot of competition ever since financial sector reforms were started in the country. Walk-in business is a thing of past and banks are now on their toes to capture business. Banks therefore, are now competing for increasing their retail business. There is a need for constant innovation in retail banking. This requires product development and differentiation, micro-planning, marketing, prudent pricing, customization, technological up gradation, home / electronic / mobile banking, effective risk management and asset liability management techniques. The banking sector in India is expected to take care of the significant changes that are taking place and have to respond to the changing expectations of stake holders of economy. 


\section{REFERENCES}

1. Rangarajan, C. "Innovations in Banking - The Indian Experience - Impact on Deposits and Credit," Oxford \& IBH Publishing Company

2. Satyanarayana, K. "Profitability Analysis of Banks in India a Basic Framework", National Institute of Banking and Management, Pune, Seminar material, February 14-18, 2005.

3. R. Magesh (2010), "A study on quality of services as a tool for enhancement of customer satisfaction in Banks, Global Journal of Finance and Management, Chennai, vol 2, no. 1, pp. 423133.
4. Bhayani, S.J. "Retail Banking Awareness: An empirical analysis" Indian Journal of marketing.

5. Sultan Singh \&Komal (2009), "Impact of ATM on customer satisfaction", Business intelligence journal, India, vol2, No.2.

6. Vasant Desai, "Indian Banking; Nature and Problems", Humalaya Pub. House, Mumbai, 1991, pp.11-25.

7. Vepa. Kamesham, "Challenges ahead in Distribution Channels in Urban and Rural India", National Institute of Banking and Management, Pune, Seminar material, February 14-18, 2005. 